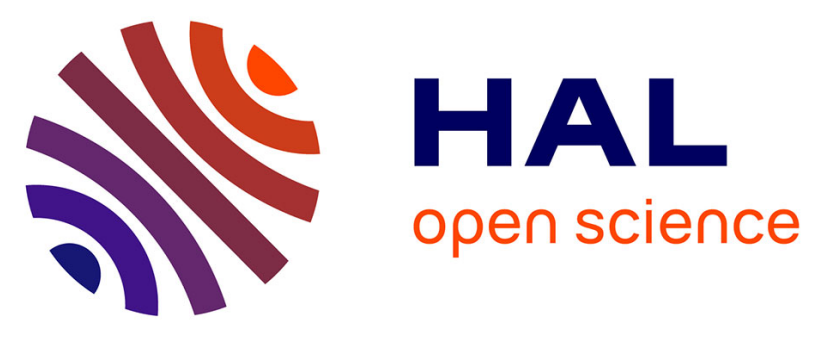

\title{
Influence of discharge variability on denudation rates and relief : example from the south-eastern margin of the Massif Central, France
}

Clement Desormeaux, Vincent Godard, Dimitri Lague, Lucilla Benedetti, Jules Fleury, Guilaume Duclaux

\section{To cite this version:}

Clement Desormeaux, Vincent Godard, Dimitri Lague, Lucilla Benedetti, Jules Fleury, et al.. Influence of discharge variability on denudation rates and relief: example from the south-eastern margin of the Massif Central, France. EGU General Assembly 2021, Apr 2021, Paris, France. 10.5194/egusphereegu21-9984 . hal-03454826

\section{HAL Id: hal-03454826 \\ https://hal.science/hal-03454826}

Submitted on 29 Nov 2021

HAL is a multi-disciplinary open access archive for the deposit and dissemination of scientific research documents, whether they are published or not. The documents may come from teaching and research institutions in France or abroad, or from public or private research centers.
L'archive ouverte pluridisciplinaire HAL, est destinée au dépôt et à la diffusion de documents scientifiques de niveau recherche, publiés ou non, émanant des établissements d'enseignement et de recherche français ou étrangers, des laboratoires publics ou privés.

\section{(c)(1)}

Distributed under a Creative Commons Attribution| 4.0 International License 
EGU21-9984

https://doi.org/10.5194/egusphere-egu21-9984

EGU General Assembly 2021

(c) Author(s) 2021. This work is distributed under

the Creative Commons Attribution 4.0 License.

\section{Influence of discharge variability on denudation rates and relief : example from the south-eastern margin of the Massif Central, France}

Clement Desormeaux ${ }^{1}$, Vincent Godard ${ }^{1}$, Dimitri Lague ${ }^{2}$, Lucilla Benedetti ${ }^{1}$, Jules Fleury ${ }^{1}$, and Guilaume Duclaux ${ }^{3}$

${ }^{1}$ Aix-Marseille University, CNRS, IRD, INRAE, CDF - CEREGE - France

${ }^{2}$ University Rennes, CNRS, OSUR, - Geosciences Rennes - France

${ }^{3}$ University Cote d'Azur, CNRS, OCA, IRD - Geoazur - France

The evolution of continental relief results from the combined action of tectonic and climatic forcings. These processes do not act continuously but often through punctual events (earthquakes, major floods, landslides) whose integrated action over time (100 Kyr to Myr) leads to the formation of landscapes. The distribution of these extreme events is often described by statistical functions involving power-law relationships between frequency and magnitude, which, coupled with the non-linearity of the geomorphological response and threshold effects for the activation of erosion agents, leads to a complex and often poorly understood relief dynamics.

Studying the influence of discharge variability helps to better constrain river incision and longterm relief evolution. The south-eastern margin of the Massif Central (France) is a very interesting target for such investigations because it presents episodes of very intense precipitation focused on the relief resulting in marked differences in the statistical discharges distributions across the landscape. Some theoretical river incision models incorporate such variability (Lague et al., 2005) but they have been confronted with real data only in a limited number of cases (DiBiase et al., 2011; Scherler et al., 2017; Campfort et al., 2020). Here we test these models in the Massif Central area and in particular on Cévennes, Ardèche and Margeride mountains by quantifying denudation rates using cosmogenic nuclides (10Be), characterizing discharges variability and performing morphological analysis on longitudinal rivers profiles.

The analysis of 326 river gauging stations allow us to observe a strong gradient in discharge variability from the external SE border to the interior of the Massif Central. The ${ }^{10} \mathrm{Be}$ concentrations measured from river sediments in 36 catchments imply a large variation of denudation rates between $29 \mathrm{~mm} / \mathrm{kyr}$ and $126 \mathrm{~mm} / \mathrm{kyr}$. We compare these denudation rates with the spatial distribution of mean annual precipitations, local relief, slope and concavity index, and also integrate all the observations in the frame of a stochastic threshold incision model. Our results confirm the complex model predictions of non-linear relationships between mean denudation rates and the channel steepness index and their dependence on hydrological variability and run-off. 
key-words : extreme events, stochastic threshold incision model, denudation rates, discharge variability, morphometric parameters, Massif Central 